\title{
ANALISIS KARAKTERISTIK LINGKUNGAN AIR DAN KOLAM DALAM MENDUKUNG BUDIDAYA IKAN
}

\section{Analysis of Water Environment Characteristics and Pools for Supporting Fish Cultivation}

\author{
Neny Rochyani \\ Staf Pengajar Fakultas Perikanan Universitas PGRI Palembang \\ Email : nenyrochyani@yahoo.com
}

\begin{abstract}
Abstrak
Faktor -faktor yang dapat menentukan kualitas air untuk kolam budidaya ikan antara lain: Keasaman atau kebasaan air, kekeruhan yang dapat menimbulkan warna dalam air, suhu air, Kandungan oksigen, dan Kandungan garam. Di lingkungan air juga tersedia pakan alami untuk pertumbuhan dan hidup ikan yaitu cacing sutra, Daphnia sp dan jentik nyamuk. Kombinasi kedua faktor tersebut akan mendukung pembudidayaan ikan di kolam agar dapat berlangsung dengan baik. Penelitian ini menitikberatkan pada analisis karakteristik kualitas air dan keberadaan pakan alami di lingkungan kolam dalam mendukung budidaya ikan. Hasil penelitian menunjukkan bahwa parameter kualitas air telah cukup baik dalam mendukung budidaya ikan disamping itu juga keberadaan pakan alami dan perkembangan hidupnya di kolam telah cukup baik sesuai dengan kondisi kualitas air yang ada. Pakan alami meskipun tidak berpengaruh signifikan dalam menunjang perkembangan pada berat dan panjang ikan akan tetapi menjadi stimulus untuk meningkatkan nafsu makan ikan sehingga dapat berkembang dengan normal.
\end{abstract}

Kata Kunci: kualitas air, pakan alami, budidaya , ikan

\begin{abstract}
Factors that can determine the quality of water for fish farming ponds include: acidity or alkalinity of water, turbidity that can cause color in water, water temperature, oxygen content, and salt content. In the water environment, natural food is also available for the growth and life of fish, namely silk worms, Daphnia sp and mosquito larvae. The combination of these two factors will support fish cultivation in the pond so that it can take place properly. This study focuses on the analysis of water quality characteristics and the presence of natural food in the pond environment in support of fish farming. The results showed that the water quality parameters had been good enough to support fish cultivation besides that the existence of natural food and the development of life in the pond had been good enough in accordance with the existing water quality conditions. Natural food, although it does not have a significant effect in supporting the development of the weight and length of the fish, will be a stimulus to increase the appetite of the fish so that they can develop normally.
\end{abstract}

Keywords: water quality, natural feed, cultivation, fish 


\section{PENDAHULUAN}

Air sebagai media untuk budidaya ikan merupakan factor utama dalam menentukan perkembang biakan ikan. Oleh karenanya, menjadi penting untuk menganalisa dan mengetahui berbagai factor yang dapat mempengaruhi kualitas air dan karakteristik alaminya untuk menyediakan sumber kehidupan alami bagi budidaya perikanan yang dilakukan.

Adapun faktor -faktor yang dapat menentukan kualitas air untuk kolam budidaya ikan antara lain : Keasaman atau kebasaan air, kekeruhan yang dapat menimbulkan warna dalam air, suhu air, Kandungan oksigen, dan Kandungan garam. Dalam hal keasaman atau kebasaan air hal yang sangat mempengaruhi adalah adanya kuantitas hydrogen yang terdapat dalam air kolam, dimana derajat keasaman dapat diukur dengan $\mathrm{pH}$ meter yaitu jika $\mathrm{pH}$ terlalu rendah maka akan bersifat asam sebaliknya jika terlalu tinggi akan bersifat basa. Kedua kondisi tersebut menyebabkan perkembangan dan pertumbuhan ikan yang ada dikolam akan sangat terganggu. Air kolam ikan normalnya berada pada level pH 6,9-8. Ada banyak kemungkinan mengapa nilai $\mathrm{pH}$ di bawah atau di atas nilai normal. Seperti penggunaan pakan untuk ikan, jasad renik dalam lingkungan kolam, penyerapan sinar matahari ataupun oleh karena air kolam yang sudah lama.

Sedangkan dalam hal kekeruhan air yang dapat menimbulkan warna ditentukan oleh: keadaan tanah dan lumpur kolam, jasad renik yang merupakan hewan yang mati dan plankton, serta jamur yang dapat mempengaruhi warna air. Pada faktor yang mempengaruhi suhu air disebabkan oleh musim, ketinggian dari permukaan laut, waktu panas dan hujan dalam satu hari, angin dan awan, kedalaman air. Untuk Kandungan oksigen di dalam air harus mencukupi. Jika kadar oksigen rendah atau kurang, maka akan menyebabkan tingkat kematian ikan didalam kolam akan tinggi pula. Sedangkan untuk kandungan garam diperlukan untuk menetralkan zat amonia dan nitrat. Tabel 1. Bahan-bahan yang digunakan.

\begin{tabular}{clll}
\hline No & \multicolumn{1}{c}{ Bahan } & \multicolumn{1}{c}{ Spesifikasi } & \multicolumn{1}{c}{ Kegunaan } \\
\hline 1 & Cacing sutra & Protein 57\% (Sumber: Hariati, 2010) & Pakan tumbuh ikan \\
2 & Jentik nyamuk & Protein 15-16\% (Sumber: Atmadjaja, 2008) & Pakan tumbuh ikan \\
3 & Daphnia pulex & Protein 47-48 \% (Sumber: Hernawati dan Agus (2014) & Pakan tumbuh ikan \\
4 & Air kolam & $15 \mathrm{~cm}$ & Media hidup ikan \\
\hline
\end{tabular}

Amonia adalah limbah yang dihasilkan melalui pembusukan kotoran ikan.

Faktor utama lain dalam pertumbuhan dna perkembangan ikan di kolam adalah tersedianya pakan alami. Peran pakan alami hingga saat ini belum dapat tergantikan secara menyeluruh. Disamping sebagai sumber protein, karbohidrat dan lemak, pakan alami terutama mikroalga merupakan sumber utama asam lemak esensial yang dibutuhkan untuk pertumbuhan larva. Pemberian pakan yang berkualitas dan diberikan dalam jumlah yang cukup akan memperkecil persentase mortalitas larva ikan atau udang (Putri, 2013). Setidaknya ada tiga jenis pakan alami yang biasanya diberikan untuk benih ikan mas koki dalam suatu pemeliharaan (pembesaran) yaitu cacing sutra, Daphnia sp dan tersebut mempunyai kandungan nutrisi (gizi) yang berbeda.

Menurut Rohmah (2016) bahwa kandungan nutrisi yang terdapat dalam pakan sangat berpengaruh terhadap hasil panen, yang merupakan tujuan akhir dari proses budidaya. Nutrisi yang baik, tentunya akan memacu pertumbuhan yang baik pula. Terkait hal itu, perlu adanya sebuah penelitian tentang jenis pakan alami yang berbeda sehingga bisa diketahui jenis pakan alami mana, yang sesuai dengan pertumbuhan ikan. Penelitian ini menitik beratkan kepada karakteristik kualitas air kolam serta peran ketersediaan pakan alami dalam mempengaruhi perkembangbiakan dan budidaya ikan di kolam.

\section{METODE PENELITIAN}

Penelitian dilakukan pada bulan Juni sampai dengan Agustus 2017 bertenpat di Kampus C Universitas PGRI Palembang.

\section{Bahan Dan Alat}

a. Bahan

Bahan-bahan yang digunakan pada pelaksanaan penelitian ini dapat dilihat pada Tabel 1 berikut ini:. jentik nyamuk. Padahal ketiga jenis pakan alami 


\section{b. Alat}

Peralatan yang digunakan pada penelitian ini seperti pada Tabel 2 berikut ini:

Tabel 2. Alat - alat yang Digunakan

\begin{tabular}{clll}
\hline No & \multicolumn{1}{c}{ Alat } & \multicolumn{1}{c}{ Spesifikas } & \multicolumn{1}{c}{ Kegunaan } \\
\hline 1 & Aerator & 9 buah & Menyuplai oksigen \\
2 & pH meter & pH meter water quality monitor $:(0.01 \mathrm{pH})$ & Mengecek derajat keasaman \\
3 & Termometer & Lotus, termometer air raksa $:\left(1^{\circ} \mathrm{C}\right)$ & Mengukur suhu \\
4 & DO meter & DO meter lutron DO $5509:(0.01 \mathrm{mg} / \mathrm{l})$ & Mengecek oksigen terlarut \\
5 & Skopnet & - & Mengambil benih \\
6 & Ember & Ember plastik muatan $15 \mathrm{~kg}(2 \mathrm{buah})$ & Tempat wadah air \\
\hline
\end{tabular}

\section{Pelaksanaan Penelitian}

Metode penelitian yang dilakukan merupakan metode ekperimen dengan menggunakan Rancangan Acak Lengkap (RAL) dengan 3 perlakuan yang masing-masing perlakuan dilakukan 3 kali ulangan. Adapun taraf perlakuan penelitian ini adalah sebagai berikut :

Perlakuan A : Pemeriksaan kondisi kualitas air

Perlakuan B : Pemeriksaan keberadaan jentik dan cacing pada kolam

Perlakuan C : pemeriksaan pakan alami Daphnia pulex pada kolam

\section{Prosedur Penelitian}

\section{a. Persiapan tempat Penelitian}

Tempat penelitian ini yaitu kolam ikan berukuran 400X300X30 cm. Dimana air yang ada berasal dari air tanah dan air hujan yang mengendap di kolam ikan.

\section{b. Pengamatan kualitas fisik air}

Pengamatan dilakukan terhadap keadaan fisik air yang berupa warna dan bau ikan, disamping itu secara visual dapat diamati perubahan pada kondisi fisik air selama beberapa waktu baik dalam hari maupun minggu.

\section{c. Pengamatan Ketersediaan Pakan alami}

Dalam penelitian ini, keberadaan pakan alamiah berupa cacing sutera, jentik nyamuk dan

Tabel 3. Hasil Pengamatan Kualitas Air selama Penelitian

\begin{tabular}{lcccc}
\hline \multicolumn{1}{c}{ Parameter } & Satuan & \multicolumn{2}{c}{ Rata-rata } & SNI 06-6989.23-2005 \\
\cline { 3 - 4 } & & Terendah & Tertinggi & \\
\hline Suhu air & ${ }^{0} \mathrm{C}$ & 26,9 & 28,6 & \\
Oksigen terlarut & $\mathrm{mg} / \mathrm{l}$ & 2,75 & 3,7 & Kisaran $27 \pm 28{ }^{\circ} \mathrm{C}$ \\
pH & $\mathrm{Unit}$ & 6,9 & 8,3 & Minimun 4 \\
Amonia $\left(\mathrm{NH}_{3}\right)$ & $\mathrm{mg} / \mathrm{l}$ & 0,02 & 0,17 & $6,5-8,5$ \\
\hline
\end{tabular}

Sumber: Pengolahan Data Sekunder

Kualitas air selama penelitian dapat dijelaskan sebagai berikut.

a. Suhu

Berdasarkan hasil pengamatan, diperoleh bahwa selama penelitian suhu air terendah
Daphnia sp. diamati dan dianalisa keberadaannya, untuk memastikan bahwa didalam kolam pemeliharaan ikan nantinya telah terdapat pakan alami.

\section{Parameter yang Dianalisis \\ Pengukuran Kualitas Air}

Pengukuran kualitas air yaitu meliputi $\mathrm{pH}$, suhu dan oksigen terlarut (DO). Pengukuran $\mathrm{pH}$ dan suhu di lakukan setiap hari, selanjutnya pengukuran oksigen terlarut (DO) di lakukan di awal, tengah dan akhir penelitian.

\section{Analisa Data}

Pada bagian ini setelah data yang diperlukan terkumpul, maka data tersebut akan diolah sehingga dari hasil pengolahan itu nantinya ditarik kesimpulan guna menjelaskan masalah yang dirumuskan.

\section{HASIL DAN PEMBAHASAN}

\section{Kualitas Air}

Kondisi kualitas air selama penelitian berlangsung masih dapat ditoleransi oleh ikan mas koki (Carassius auratus) pada pakan cacing sutera, jentik nyamuk, dan Daphnia sp. Pengamatan kualitas air selama penelitian disajikan pada Tabel 3. 


\section{b. $\mathbf{p H}$}

Berdasarkan hasil pengamatan, diperoleh bahwa $\mathrm{pH}$ air selama penelitian berkisaran antara 6,9 hingga 8,3. Menurut Shao, K.-T. and P.L. Lim (1991) menjelaskan bahwa $\mathrm{pH}$ yang baik untuk ikan mas koki berkisar 6.5 - 8.5.

\section{c. Oksigen terlarut}

Berdasarkan hasil pengamatan, diperoleh bahwa oksigen terlarut berkisaran yang terendah 2,7 mg/l dan yang tertinggi 3,7 mg/l. Menurut Zhadin dan Gerd (1963) menjelaskan bahwa ikan mas koki dapat bertahan pada tingkat oksigen terlarut kisaran $4 \mathrm{mg} / \mathrm{l}$.

\section{d. Kadar Amonia (NH3)}

Kadar Amonia $\left(\mathrm{NH}_{3}\right)$ dari data pengamatan rata-rata terendah $0,02 \mathrm{mg} / \mathrm{l}$ dan yang tertinggi $0,17 \mathrm{mg} / \mathrm{l}$. Hal ini sesuai dengan pendapat Watson (2004), yang menyatakan bahwa kisaran amonia yang baik untuk taraf kelangsungan hidup ikan adalah $0,05 \mathrm{mg} / \mathrm{l}$, jadi kisaran yang dicapai pada penelitian ini masih dalam batas toleransi unuk pertambahan ikan.

\section{Keberadaan Cacing Sutera}

Berdasarkan hasil pengamatan, diperoleh bahwa selama penelitian suhu air terendah terendah $26,9^{\circ} \mathrm{C}$ dan tertinggi $28,6^{\circ} \mathrm{C}$. Hal ini senada penjelasan Tierra (1991) yang menyatakan bahwa suhu air yang ideal untuk perkembangan ikan berkisar antara $27^{\circ} \mathrm{C}$ hingga $28^{\circ} \mathrm{C}$. Selain itu, menurut Khairuman dalam Hariati (2010), kandungan karbohirat cacing sutera adalah $2,04 \%$ dengan lemak mencapai $13,30 \%$.

Keberadaan cacing sutera dengan kondisi kualitas air kolam yang ada akan mendukung perkembangan pakan alami ini didalam lingkungan kolam sehingga dapat memenuhi salah satu kebutuhan pakan ikan dalam perkembangannya. Keberadaan cacing sutera akan merangsang nafsu makan ikan sehingga akan mempengaruhi perkembanngan berat dan tumbuh ikan diiringi dengan pemberian pakan tambahan lainnya. Menurut Prayogo, dkk. (2012), perubahan pertambahan kedua parameter tersebut berbanding lurus, semakin bertambah berat tubuh semakin bertambah pula panjang tubuh ikan.

\section{Keberadaan Jentik Nyamuk}

Kolam ikan yang terbuka akan mendorong tumbuh kembangnya jentik nyamuk di lingkungan kolam. Hal ini didukung dengan kondisi alamiah kolam yang merupakan habitat alami perkembang biakan nyamuk. Keberadaan jentik nyamuk dengan kondisi kualitas air kolam yang ada akan mendukung perkembangan pakan alami ini didalam lingkungan kolam sehingga dapat memenuhi salah satu kebutuhan pakan ikan dalam perkembangannya. Keberadaan jentik nyamuk tidaklah berpengaruh signifikan terhadap perkembangan berat dan tumbuh ikan di kolam (Sutrisno, 2017) namun demikian, adanya jentik nyamuk akan merangsang nafsu makan ikan sehingga pada akhirnya akan mempengaruhi perkembanngan berat dan tumbuh ikan diiringi dengan pemberian pakan tambahan lainnya.

\section{Keberadaan Daphnia sp.}

Perkembangan daphnia Sp pada Kolam ikan yang terbuka akan semakin baik dengan didukung oleh kondisi lingkungan kolam. Hal ini didukung dengan kondisi alamiah kolam dengan kualitas air yang memungkingkan berkembang biaknya pakan pakan alamiah di kolam. Keberadaan daphnia Sp tidaklah berpengaruh signifikan terhadap perkembangan berat dan tumbuh ikan di kolam (Sutrisno, 2017), namun demikian, adanya jentik nyamuk akan merangsang nafsu makan ikan sehingga pada akhirnya akan mempengaruhi perkembanngan berat dan tumbuh ikan diiringi dengan pemberian pakan tambahan lainnya.

Berdasarkan hasil penelitian yang telah dilakukan dengan mengambil sampel pertumbuhan ikan Mas Koki (Carassius auratus) melalui perlakuan pakan alami yang berbeda cacing sutera, jentik nyamuk dan Daphnia sp, didapatkan hasil rata-rata pertambahan panjang ikan Mas Koki selama penelitian (Sutrisno, 2017).

Dari hasil perhitungan yang telah dilakukan, didapatkan pertambahan panjang rata-rata $(\mathrm{cm})$ Ikan Mas Koki (Carassius auratus) pada masing-masing perlakuan yang memiliki perbedaan. Pada perlakuan pakan cacing sutera panjang ikan rata-rata yaitu 3,599 $\mathrm{cm}$, sedangkan pada perlakuan pakan jentik nyamuk panjang ikan menjadi $2,756 \mathrm{~cm}$. Selanjutnya, pada perlakuan pakan daphnia sp. panjang ikan mas koki yaitu $3,360 \mathrm{~cm}$. Pertambahan panjang ikan mas koki dari hari pertama sampai kehari 30 mulai semakin terlihat peningkatan secara signifikan dari masingmasing perlakuan.

Adapun pertambahan panjang rata-rata (cm) ikan mas koki (Carassius auratus) pada berbagai perlakuan selama penelitian dapat dilihat pada Gambar 1. 


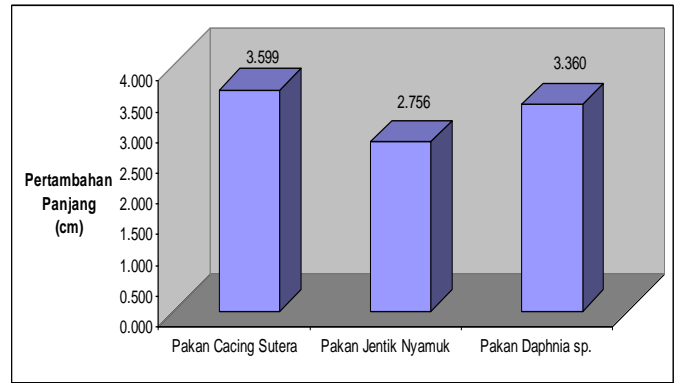

Gambar 1. Pertambahan Panjang Rata-Rata Ikan Mas Koki (Carassius auratus)

Berdasarkan hasil perhitungan kelangsungan hidup, diperoleh nilai rata-rata (ekor) kelangsungan hidup ikan Mas Koki (Carassius auratus) pada masing-masing perlakuan memiliki perbedaan. Pada perlakuan pakan cacing sutera kelangsungan hidup ikan rata-rata yaitu 20 ekor atau $100 \%$ artinya semua ikan dalam keadaan hidup, sedangkan pada perlakuan pakan jentik nyamuk kelangsungan hidup ikan menjadi 19 ekor atau 96,67\%. Selanjutnya, pada perlakuan pakan Daphnia sp. kelangsungan hidup ikan mas koki yaitu 18 ekor atau 90,56\%. Kelangsungan hidup ikan mas koki dari hari pertama sampai kehari 30 mulai semakin terlihat peningkatan secara signifikan dari masing-masing perlakuan.

Dari hasil pengujian proksimat juga menyatakan bahwa kandungan protein yang terdapat pada perlakuan P3 merupakan tertinggi dibandingkan dengan perlakuan yang lain. Selain itu, berdasarkan hasil pengamatan, diperoleh bahwa selama penelitian suhu air terendah $27^{\circ} \mathrm{C}$ dan tertinggi $28,7^{\circ} \mathrm{C}$.

Adapun kelangsungan hidup rata-rata (ekor) ikan mas koki (Carassius auratus) pada berbagai perlakuan selama penelitian dapat dilihat pada Gambar 2 di bawah ini.

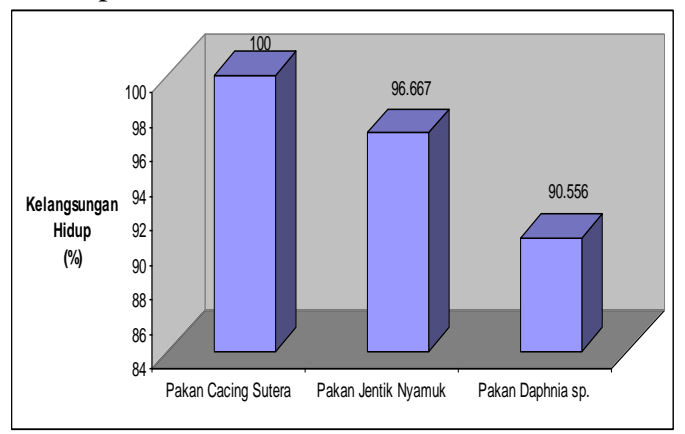

Gambar 2. Kelangsungan hidup Rata-Rata Ikan Mas Koki (Carassius auratus)

\section{KESIMPULAN DAN SARAN}

\section{Kesimpulan}

Berdasarkan hasil penelitian yang telah dikemukakan sebelumnya dapat disimpulkan sebagai berikut.

a. Kondisi parameter kualitas air pada kolam sangat mendukung untuk tumbuh kembangya ikan didalam kolam.

b. Keberadaan pakan alami yaitu cacing sutera, jentik nyamuk dan Daphnia sp. berkembang dengan baik dan sangat mendukung ketersediaan pakan alami bagi perkembangan ikan di dalam kolam.

c. Pakan alami yang ada bersifat sebagai stimulant untuk merangsang nafsu makan ikan didalam kolam dan haruslah didukung dengan pakan tambahan guna perkembangan ikan.

\section{Saran}

Berdasarkan kesimpulan, maka disarankan sebagai berikut :

a. Penelitian ini hendaknya dapat dijadikan sebagai salah satu alternatif untuk menggunakan kondisi alamiah kolam dalam menyediakan pakan alami berupa kadar cacing sutera yang sesuai sehingga mendapatkan hasil yang lebih sempurna.

b. Dijadikan dasr penelitian lanjutan yang lebih luas tentang pakan alami berdasarkan karakteristik lingkungan yang disinergikan dengan efisiensi penggunaan pakan untuk budidaya ikan di kolam tambak.

\section{DAFTAR PUSTAKA}

Hariati, Vivi Endar. 2010. Analisis Pemberian Pakan Tubifex sp. Hasil Kultur Massal Menggunakan Fermentasi Kotoran Ayam, Roti Afkir dan Ampas Tahu Terhadap Performa Pertumbuhan Dan Kelulushidupan Larva Lele (C. gariepenus). Prosiding Seminar Nasional Tahunan Ke-V Hasil-Hasil Penelitian Perikanan dan Kelautan. Program Studi Budidaya Perairan.

Prayogo, H.H., R. Rostika, dan I. Nurruhwaty. 2012. Pengkayaan Pakan yang Mengandung Maggot dengan Tepung Kepala Udang sebagai Sumber Karotenoid Terhadap Penampilan Warna dan Pertumbuhan Benih Rainbow Kurumoi (Melanotaenia parva). Jurnal Perikanan dan Kelautan

Putri, Berta. 2013. Pemanfaatan Air Kelapa Sebagai Pengkaya Media Pertumbuhan Mikroalga Tetraselmis sp. Jurusan 
Budidaya Perairan Fakultas Pertanian Universitas Lampung.

Rohmah. 2016. Pengaruh Berbagai Pakan Alami Jenis Cacing Terhadap Pertumbuhan dan Kelangsungan Hidup Ikan Tengadak (Barbonimus scwanenfeldii). Fakultas Perikanan dan Ilmu Kelautan, Universitas Muhammadiyah Pontianak

Shao, K. T. \& P. L. Lim. 1991. Fishes of freshwater and estuary. Encyclopedia of field guide in Taiwan. Recreation Press, Co., Ltd., Taipei. Vol. 31. 240 p. In Froese, R. \& D. Pauly. Editors. 2012. FishBase. World Wide Web electronic publication. www.fishbase.org, version (10/2012).

Watson CH. 2004. Method for the determination of ammonium in cigarette tobacco using ion chromatography. RTP : Regulatory toxicology and pharmacology

Zhadin VI and Gerd SV. 1963. Fauna and Flora of the River, Lakes and Reservoirs of the USSR. Israel Prgram for scientific translation, Jerusalem, 626 PP. 